\title{
Phytotoxicity OF SiCyOS DEPPEI DURING TOMATO GERMINATION AND ITS EFFECTS ON THE ROLE OF ABA AND CELL WALL ENZYMES
}

\author{
Aurora Lara-Núñez ${ }^{1}$, José Luis Ventura-Gallegos², Ana Luisa Anaya ${ }^{1}$ \\ and Rocío CruZ-Ortega ${ }^{1,3}$ \\ 'Laboratorio de Alelopatía. Departamento de Ecología Funcional. Instituto de Ecologia, \\ Universidad Nacional Autónoma de México, México, D.F., México \\ ${ }^{2}$ Departamento de Medicina Genómica y Toxicología Ambiental. Instituto de Investigaciones Biomédicas, \\ Universidad Nacional Autónoma de México, México, D.F., México \\ ${ }^{3}$ Corresponding author: rcruz@ecologia.unam.mx
}

\begin{abstract}
Sicyos deppei is a harmful weed that grows in central Mexico, decreasing crop productivity by allelochemical release via lixiviation of the aerial organs through raining. Sicyos deppei aqueous leachate is phytotoxic to tomato seed germination causing various metabolic alterations, such as high levels of abscisic acid, which delay germination and inhibit radicle growth. To determine whether abscisic acid catabolism was involved in the delay of germination caused by $S$. deppei, tomato seeds were exposed to diniconazole, an ABA catabolism-inhibitor, and subsequently the activity of cell wall-degrading enzymes (endo- $\beta$ mannanase, $\alpha$-galactosidase, exo-polygalacturonase, and $\beta$-1,3-glucanase) was estimated in the presence of ABA, diniconazole and $S$. deppei aqueous leachate. Results showed that during germination, there is a delay in ABA degradation and the activity of the four cell wall-degrading enzymes evaluated was inhibited. Cell cycle was analyzed to characterize the inhibition of radicle growth during post-germination in the roots of treated seedlings. The phytotoxic aqueous leachate of $S$. deppei interfered with it, altering the expression of two cell cycle marker genes $C D K B 2 ; 1$ and $C y c B 2 ; 1$, thereby reducing cell division. In summary, the delay in tomato germination through $S$. deppei leachate reflects first that there is a delay in ABA catabolism, and second there is an alteration of cellular processes that interfere with cell cycle and inhibit radicle growth during postgermination.
\end{abstract}

Key words: CDK, cell wall degrading enzymes, cyclins, Solanum lycopersicum.

Resumen: Sicyos deppei es una maleza agresiva que se distribuye en la zona central de México que disminuye la productividad de cultivos por la liberación de aleloquímicos a través de la lixiviación de sus hojas por la lluvia. El lixiviado acuoso de $S$. deppei es fitotóxico durante la germinación del tomate, alterando varios procesos metabólicos, incluyendo aumentos en los niveles de ABA, retraso en el tiempo de germinación e inhibición del crecimiento radicular. En este trabajo se evaluó si el lixiviado de $S$. deppei interfiere con el catabolismo del ABA, y retrasa la germinación; para esto las semillas de tomate fueron expuestas a un inhibidor del catabolismo del ABA, el diniconazol. Posteriormente, se evaluó la actividad de las enzimas encargadas de la degradación de la pared celular (endo- $\beta$-mananasa, $\alpha$-galactosidasa, exo-poligalacturonasa y $\beta$-1,3-glucanasa) en semillas expuestas a ABA exógeno, al diniconazol y al lixiviado de $S$. deppei. Los resultados mostraron un retraso en la degradación del ABA durante la germinación y una inhibición de la actividad de las enzimas analizadas. Después de la germinación, se evaluó la inhibición de la radícula a partir de semillas expuestas a $S$. deppei. Se observó que la expresión de los genes marcadores del ciclo celular $C D K B 2 ; 1$ y $C y c B 2 ; 1$, fue modificada, disminuyendo la división celular. Se concluye que el retraso de la germinación del tomate debida al efecto fitotóxico de $S$. deppei se puede explicar por alteraciones de procesos celulares que interfieren con el catabolismo del ABA y con el ciclo celular durante la post-germinación.

Palabras clave: ciclinas, CDK, enzimas degradadoras de pared celular, Solanum lycopersion.

$S^{t}$ cyos deppei G.Don (Cucurbitaceae) is a harmful, endemic weed that grows in the temperate regions of central Mexico, interfering with crop plants and decreasing its productivity (Villaseñor-Ríos and Espinosa-García, 1998).
Sicyos deppei interference occurs through the release of allelochemicals via lixiviation through the aerial organs after raining. The aqueous leachate releases from the aerial organs (leaves and stems) of $S$. deppei causes severe phytotoxic- 
ity in diverse crop plants, primarily in tomato (Cruz-Ortega et al., 1998; Romero-Romero et al., 2002). We studied the mechanism underlying the activity of the aqueous leachate of $S$. deppei, using tomato (Solanum lycopersicum, before Lycopersicon esculentum, Mill, Solanaceae) as a model plant. We have shown through in vitro assays that watersoluble compounds delay tomato seed germination and inhibit radicle growth. Sicyos deppei phytotoxicity has been associated with diverse metabolic processes, such as the inhibition of the $\mathrm{H}^{+}$-ATPase in the plasma membrane and tonoplast (Romero-Romero et al., 2005), increases in ROS levels, membrane lipid peroxidation, effects on the activity of antioxidant enzymes, and the inhibition of NADPH oxidase activity (Lara-Núñez et al., 2006). Furthermore, the delayed of root protrusion in seeds exposed to $S$. deppei aqueous leachate has been associated with the reduced activity of cell wall-degrading enzymes, changes in carbohydrate content, and increased levels of abscisic acid (ABA) (Lara-Núñez et al., 2009).

Germination is initiated through seed imbibition by water uptake, which results in local cell wall loosening to initiate cell growth (Crosgrove, 1996), followed by the repair of membrane and cellular structures, and an increase in metabolic activity (Bewley and Black, 1994). The initiation of growth is tightly regulated through environmental and hormonal signals. The process is antagonistic, with ABA inhibiting germination and gibberellins stimulating it (Finch-Savage and Leubner-Metzger, 2006). The mechanism by which ABA inhibits germination is complex, and there is evidence that this plant regulator acts as a down-regulator of cell wall degradation metabolism (Toorop et al., 2000). During germination in tomato seeds and before root emergence, an important breakdown of mannan polymers in the embryo and micropylar endosperm occurs through endo- $\beta$-mannanase. After germination, a set of three enzymes, endo- $\beta$-mannanase, $\beta$-mannosidase and $\alpha$-galactosidase, cooperatively function to complete the degradation of cell wall galactomannans (Feurtado et al., 2001). ABA negatively regulate the activity of endo- $\beta$-mannanase and $\alpha$-galactosidase (Toorop et $a l ., 2000)$, but accessory enzymes, such as exo-polygalacturonase, $\beta$-mannosidase and $\beta$-1,3-glucanase, also participate in cell wall degradation and eventual endosperm weakening (Nonogaki et al., 2000; Leubner-Metzger, 2003).

The cell cycle is a crucial process that allows cell proliferation during germination and postgermination. Iterative cell divisions lead to radicle elongation and cell differentiation (Inzé and De Veylder, 2006). Cyclin-dependent kinases (CDKs) govern the plant cell cycle, and different CDK-cyclin complexes phosphorylate a plethora of substrates at the G1-to-S and G2-to-M transition points, triggering the onset of DNA replication and mitosis, respectively (Inzé and De Veylder, 2006, for a review see Tank and Thaker, 2011).

The cell cycle is controlled through both internal and external stimuli, for which plant growth regulators are key substances. Among them, auxins and cytokinins have been well documented in controlling the expression of several cell cycle genes (del Pozo et al., 2004); of these, auxins stimulate the cell cycle during germination at two levels: gene transcription and kinase activation. Both, auxins and cytokinins shorten the G1 phase during germination and stimulate DNA synthesis. The biochemical perception of phytoregulators triggers cell cycle stimulation, and this perception might follow different pathways (Vázquez-Ramos and Lara-Núñez, 2008).

Based on our findings that ABA levels are higher in germinating tomato seeds exposed to Sicyos deppei aqueous leachate (Lara-Núñez et al., 2009) and considering the importance of ABA in germination and the cell cycle in postgermination, the aim of this study was to determine whether $S$. deppei aqueous leachate affects the catabolism of ABA by comparing the responses to diniconazole (an inhibitor of ABA catabolism, Zhu et al., 2009) with S. deppei aqueous leachate on tomato seed germination; assess the effects of ABA on cell wall loosing by testing the activity of four cell wall degrading enzymes: endo- $\beta$-mannanase, $\alpha$-galactosidase, $\beta$-1,3-glucanase and exo-polygalacturonase, in the presence of exogenous ABA and diniconazole, and compare these effects to those of $S$. deppei aqueous leachate on the activity of these enzymes; and characterize the differential gene expression of three regulating cell cycle proteins, $C D K B 2 ; 1, C y c B 2 ; 1$ and $C y c D 3 ; 1$, during germination and after the root protrusion (postgermination) of tomato seeds under allelochemical stress through estimating cell cycle progression using flow cytometry analysis.

\section{Materials and methods}

Plant material and bioassays. The aerial organs (leaves and stems) of Sicyos deppei were collected in a crop field at Xochimilco, Mexico City. Samples were collected by taking several plants randomly at different places of the crop field. Plants were at vegetative stage (before flowering), fresh and healthy with no herbivore or disease symptoms. Collected plants were placed into paper bags and transported to the laboratory, where they were air-dried $\left(27-30{ }^{\circ} \mathrm{C}\right)$ and used to prepare an aqueous leachate. Tomato (Solanum lycopersicum, L. cv. Rio Grande, Solanaceae) seeds were obtained from Sun Seeds (Parma, Idaho, USA).

Allelopathic aqueous leachate was obtained by soaking the aerial organs of Sicyos deppei $(1 \mathrm{~g} / 100 \mathrm{~mL})$ in sterile distilled water for $3 \mathrm{~h}$. This leachate was filtered through Whatman paper (No. 4), followed by filtration through two sterile Millipore membranes $(0.45 \mu \mathrm{m}$ and $0.2 \mu \mathrm{m})$. The osmotic potential of the aqueous leachate of $S$. deppei was measured using a freezing-point osmometer (Osmette A, Precision System Inc. Natick, MA, USA).

Bioassays were performed under sterile conditions in a laminar flow hood. The tomato seeds were germinated in 
Petri dishes $(60 \mathrm{~mm})$ for the consequent application of the treatments: aqueous Sicyos deppei leachate $(1 \% \mathrm{w} / \mathrm{v})$ containing $2 \%$ of agar $(1: 1 \mathrm{v} / \mathrm{v})$ to obtain a final concentration of $0.5 \%$ leachate and $1 \%$ agar; 2,5 , and $10 \mu \mathrm{M} \mathrm{ABA}$ and 2 , 5, 10 and $20 \mu \mathrm{M}$ diniconazole were added to the agar, separately (data not shown). For the controls, seeds were germinated on media containing only $1 \%$ agar. A diniconazole mixture of $\mathrm{Z}$ and $\mathrm{E}$ isomers was obtained from Riedel-de Haën, and ( \pm )-Abscisic acid was purchased from Sigma.

To perform the bioassays for the germination and radicle growth experiments, 12 seeds were placed onto Petri dish with five replicates per treatment. The germination rate and radicle protrusion were registered from 42 to $72 \mathrm{~h}$. To determine the ABA content and analyze cell wall enzyme activity, RNA was extracted from the imbibed seeds obtained from 20 Petri dishes containing twenty-five seeds each. For the bioassays, the seeds were collected after 24,36 , and 48 h. For the RNA extractions, the seeds were collected at 3, 6, $9,12,24,36$, and $48 \mathrm{~h}$. The seeds were immediately frozen in liquid nitrogen and stored at $-70{ }^{\circ} \mathrm{C}$ until further use. All bioassays were performed on plates incubated in a growth chamber at $25{ }^{\circ} \mathrm{C}$ in dark. A seed was considered germinated when the radicle was at least $1 \mathrm{~mm}$ length (Bewley and Black, 1994); the control seeds germinated at $36 \mathrm{~h}$, and the treated seeds germinated after $40 \mathrm{~h}$. The radicle length was measured at different times using a vernier caliper.

Enzyme assays. All spectrophotometric analyses were conducted using a Varian Spectrophotometer (Cary 50-Bio, Varian Inc. Palo Alto, California, USA) or, where indicated, a microplate reader was used (BioTek, ELx808, BioTek Instruments, Inc., Winooski, VT, USA). The protein concentration was determined according to the Bradford method (1976). All protein extraction procedures for the activity assays were performed at $4{ }^{\circ} \mathrm{C}$. The linearity of the reactions was monitored over the duration of the assays.

$\alpha$-Galactosidase assays (EC 3.2.1.22). The $\alpha$-galactosidase assay was adapted from Leung and Bewley (1981). Briefly, $100 \mathrm{mg}$ of pulverized tissue was homogenized using $200 \mu \mathrm{L}$ $0.1 \mathrm{M}$ HEPES-KOH/ $0.5 \mathrm{M} \mathrm{NaCl}(\mathrm{pH} 8.0)$ and centrifuged at $21,000 \times \mathrm{g}$ for $10 \mathrm{~min}$. The supernatant was collected and adjusted to final volume of $0.5 \mathrm{~mL}$. Prior to $\alpha$-galactosidase assay, a solution of polyethylenitimine (10\%) was added to obtain a final concentration of $2 \%$. The activity was assayed in a 96-well microtiter-assay plate. The assay mixture consisted of $75 \mu \mathrm{L}$ of Mclluvaine buffer $\mathrm{pH} 4.5$ (0.1 M citric acid, $0.2 \mathrm{M} \mathrm{Na}_{2} \mathrm{HPO}_{4} ; 1: 1.08$ ratio), $15 \mu \mathrm{L}$ of substrate (10 mM $p$-nitrophenyl- $\alpha$-D-galactopyranoside) (Sigma) dissolved in Mclluvaine buffer $\mathrm{pH} 5$ (1:1.1 ratio) and $60 \mu \mathrm{L}$ of enzyme extract. After incubation at $37{ }^{\circ} \mathrm{C}$ for $15 \mathrm{~min}$, the reaction was terminated with the addition of $75 \mu \mathrm{L}$ of $0.2 \mathrm{M} \mathrm{Na}_{2} \mathrm{CO}_{3}$. The yellow color was measured at $405 \mathrm{~nm}$. The control experiments involved the addition of enzyme extracts after the addition of stop solution. These controls were used as the zero calibration reading. The molar extinction coefficient for p-nitrophenol was obtained as 18,400 M-1 cm-1 (Reid and Meier, 1973) to calculate the amount of $p$-nitrophenol released in units of $\mu \mathrm{mol} \mathrm{min}^{-1} \mathrm{~g}^{-1}$. Results are the average of three replicates \pm SE.

$\beta$-1,3-Glucanase activity (EC 3.2.1.39) ( $\beta$-glucanase $[\beta(1 \rightarrow 3)$-glucanohydrolase]). Pulverized tissue was homogenized in $15 \mathrm{mM}$ Na-acetate ( $\mathrm{pH} 5.5,1: 3 \mathrm{w} / \mathrm{v})$, centrifuged at $10,000 \times \mathrm{g}$ for $5 \mathrm{~min}$; the supernatant was directly used to perform the enzyme determination. $\beta-1,3$-glucanase activity was assayed using Laminaria digitata laminarin as the substrate according to Salyers et al. (1977) and Morohashi and Matsushima (2000) with a slight modification: the assay mixture contained $0.5 \mathrm{mg}$ laminarin, $50 \mu \mathrm{mol} \mathrm{Na}$-acetate buffer $(\mathrm{pH}$ 5.5 ), and $0.1 \mathrm{~mL}$ enzyme solution in a total volume of $0.4 \mathrm{~mL}$. The mixture was incubated at $37^{\circ} \mathrm{C}$ for $30 \mathrm{~min}$ and boiled for $5 \mathrm{~min}$ to finish the reaction. A boiled enzyme control was run at the same time. No increase in glucose was observed in the boiled enzyme control. The enzyme activity was evaluated by measuring glucose formation through the GOD-POD method according to the manufacturer's instructions (Merck Ltd., Mumbai, India) in a microplate reader. Results represent the average of three replicates \pm SE.

The endo- $\beta$-mannanase (EC 3.2.1.78) activity was assayed using the modified gel diffusion method (Still et al., 1997). Agarose $(0.8 \%$ [w/v]) plates containing $0.05 \%(\mathrm{w} / \mathrm{v})$ locust bean galactomannan (Sigma, St. Louis) were solidified. The wells were formed on the plates through scoring with a 3-mm cork borer and removing the plug by suction. Proteins were extracted by homogenizing $100 \mathrm{mg}$ pulverized tissue in 0.1 M HEPES-KOH buffer ( $\mathrm{pH} 8.0)$. The extract was centrifuged at $21,000 \times \mathrm{g}$ for $10 \mathrm{~min}$ at $4{ }^{\circ} \mathrm{C}$. and the supernatant was adjusted to $1.5 \mathrm{~mL}$ and then samples from the protein extracts of $10 \mu \mathrm{L}$ were applied to the wells. The plates were incubated at $25{ }^{\circ} \mathrm{C}$ for $24 \mathrm{~h}$. After incubation, the agarose gel plates were stained with $0.5 \%(\mathrm{w} / \mathrm{v})$ Congo red dye. The hydrolyzed areas were visible as clear circles on a dark background. The diameter of the hydrolyzed area is logarithmically related to the enzyme activity and was quantified by comparison with endo- $\beta$-mannanase standards (Megazyme, Bray, Eire) as described in Still et al. (1997). The results are the average of three replicates \pm SE.

Exo-polygalacturonase (EC 3.2.1.15). Pulverized seed tissues were homogenized in an extraction buffer $(1: 10[\mathrm{w} /$ v], $1 \mathrm{M} \mathrm{NaCl}, 2.5 \mathrm{mM}$ PMSF, $10 \mu \mathrm{M}$ leupeptin, $50 \mathrm{mM}$ $\mathrm{NaOAc}$ ) (pH 5.0). The homogenate was placed in centrifuge tubes and incubated for $30 \mathrm{~min}$ on ice. The suspension was centrifuged for $20 \mathrm{~min}$ at $10,000 \times \mathrm{g}$, and supernatant was dialyzed overnight in $12-14 \mathrm{kD}$ exclusion tubing against 50 mM NaOAc buffer (pH 5.0) according to Sitrit et al. (1999). 
The exo-polygalacturonase activity was tested by measuring the release of reducing groups from pectic acid; for this purpose the $250 \mu \mathrm{L}$ reaction contained $25 \mu \mathrm{L}$ of enzyme extract and $225 \mu \mathrm{L}$ of $2 \mathrm{mgmL}^{-1}$ citric pectin in $0.1 \mathrm{M} \mathrm{NaOAc}$ buffer, $\mathrm{pH}$ 5.0. The mixture was incubated for $30 \mathrm{~min}$ at $45^{\circ} \mathrm{C}$ and the reaction was terminated with the addition of $750 \mu \mathrm{L}$ of DNS reagent (3,5-dinitro-salicylic acid). The reactions were boiled for $10 \mathrm{~min}$ and chilled on ice. The absorbance was determined at $575 \mathrm{~nm}$, and the concentrations were estimated using a standard glucose curve (Tagawa and Kaji, 1988). The results are the average of three replicates $\pm \mathrm{SE}$.

$A B A$ content. The abscisic acid content from the control and treated seeds was determined through the ABA immunoassay detection method (Tahara et al., 1991) using a Kit from Sigma (Sigma ${ }^{\circledR}$, St Louis, MO), following the manufacturer's instructions. Detections were measured on a microplate reader, and the results are given as percentage of ABA content related to control seeds at each analyzed time.

Flow cytometry. The percentage of cell-cycle phase distribution in the control and treated seedlings were analyzed through fluorescent-activated cell sorting. Three replicates containing 150 radicle tips at 48 and $72 \mathrm{~h}$ were used for the flow cytometry analysis of nDNA contents according to the methods of Sacandé et al. (1997). The nuclei isolation was performed according to the methods of Özbingöl et al. (1999). Briefly, $1 \mathrm{~mm}$ of radicle tips were obtained and chopped in $500 \mu \mathrm{L}$ of nuclei isolation buffer $(0.2 \mathrm{M}$ mannitol; $10 \mathrm{mM}$ MES, pH 5.8; $10 \mathrm{mM} \mathrm{NaCl} ; 10 \mathrm{mM} \mathrm{KCl}$; $10 \mathrm{mM}$ spermine tetrahydrochloride; $2.5 \mathrm{mM}$ EDTA; 2.5 mM DTT; $0.05 \%$ Triton X-100 (v/v); $0.05 \%$ (w/v) $\mathrm{NaN}_{3}$. Subsequently, the homogenate was filtered through a nylon membrane $\left(10 \mu \mathrm{m}\right.$ Spectra Mesh $\left.{ }^{\circledR}\right)$. The filtered was centrifuged at 1,800 $\mathrm{g}$ for $15 \mathrm{~min}$, and the pellet was resuspended in $80 \%$ methanol in PBS. The cells were stained with $10 \mu \mathrm{g} /$ $\mathrm{mL}$ of propidium iodide solution for $30 \mathrm{~min}$ at room temperature and approximately 10,000 nuclei were analyzed using a FACS Calibur Analyzer (BD Bioscience). The data were analyzed using the CellQuest software (BD Bioscience).

Total RNA extraction and semiquantitative RT-PCR. Total RNA was isolated from all treatments using Trizol reagent from $100 \mathrm{mg}$ of pulverized tissue. The cDNA was obtained using a Retro-transcription (RT) reaction (Invitrogen) according to the supplier specifications. The synthesis of cDNA and PCR was performed from $1 \mu \mathrm{g}$ of total RNA, utilizing the Two-Step kit (Invitrogen). The PCR reactions were performed using specific primers (Table 1). The PCR reaction contained $1 \mu \mathrm{L}$ of the template, $0.2 \mathrm{mM}$ dNTPs, $0.5 \mathrm{mM}$ primers (forward and reverse), 1.5 units of RT and 1.5 units of Taq polymerase (Invitrogen) and 1X PCR buffer (Invitrogen) in a final volume of $12.5 \mu \mathrm{L}$. The RT reaction and PCR were performed in a programmable Primus Thermal Cycler (Hybaid) with an annealing temperature of $56{ }^{\circ} \mathrm{C}$. For the semiquantitative PCR, the cycle number in the linear range was empirically determined. RT conditions included $50{ }^{\circ} \mathrm{C}$ for $30 \mathrm{~min}$ and $94{ }^{\circ} \mathrm{C}$ for $2 \mathrm{~min}$, and the PCR conditions were initiated with a first step at $72{ }^{\circ} \mathrm{C}$ for $15 \mathrm{~min}$ and $94^{\circ} \mathrm{C}$ for $15 \mathrm{sec}$, followed by 35 cycles at $55^{\circ} \mathrm{C}$ for $30 \mathrm{sec}$, and $70^{\circ} \mathrm{C}$ for $45 \mathrm{sec}$, with a final extension at $72{ }^{\circ} \mathrm{C}$ for $10 \mathrm{~min}$. The PCR products created a single band at the predicted sizes: Actin $402 \mathrm{bp}, \mathrm{LeCDKB} 2 ; 1,521 \mathrm{bp}$, LeCycB2;1,541 bp, LeCycD3;1,525 bp.

All resulting products were cloned with the pGEM-T Easy Vector System 1 (Promega) and sequenced to confirm that the products corresponded to the sequence of each clone. The PCR products were analyzed on a $1.5 \%(\mathrm{w} / \mathrm{w})$ agarose gel containing $0.5-\mu \mathrm{g} \mathrm{mL}^{-1}$ of ethidium bromide. The gels were scanned and photographed for further analysis using an Imaging System (Gel Logic 100, KODAK). The PCR amplifications were performed in triplicate.

Statistical analysis. The data from all experiments, germination, ABA content, enzyme assays, and RT-PCR were analyzed using a one-way ANOVA, and a comparison using Tukey's test was performed to assess the significant differences at $P<0.05$ or less. The statistical analysis was conducted using STATISTICA software package v 6.0 (Statsoft, Inc. OK, USA).

\section{Results}

The effects of $A B A$ and Sicyos deppei aqueous leachate on tomato seed germination and radicle growth. Role of $A B A$ catabolism using diniconazole as inhibitor. A higher abscisic

Table 1. Sets of PCR primers used to amplify gene-specific regions and corresponding size of the amplified product.

\begin{tabular}{|c|c|c|c|c|c|}
\hline \multirow{2}{*}{$\frac{\text { cDNA }}{\text { LeCDKB2;1 }}$} & \multicolumn{2}{|c|}{ Primer sequence $\left(5^{\prime} \rightarrow 3^{\prime}\right)$} & \multirow{2}{*}{$\frac{\text { Location }}{46-65}$} & \multirow{2}{*}{$\begin{array}{l}\text { Size (bp) } \\
521\end{array}$} & \multirow{2}{*}{$\begin{array}{l}\text { Accession \# } \\
\text { AJ297917 }\end{array}$} \\
\hline & Sense & GGA GGC TGC TGA AAA TGC TG & & & \\
\hline & Antisense & GTA TAA GCT CTG CCA AGT CC & $548-567$ & & \\
\hline \multirow[t]{2}{*}{ LeCycB2;1 } & Sense & GAG GAG GTT TGT GCT CCA CTG GTG G & $1192-1216$ & 541 & AJ243455 \\
\hline & Antisense & AAG TTA GTA ATA ACT GTA CAT GCC C & $1709-1733$ & & \\
\hline \multirow[t]{2}{*}{ LeCycD3;1 } & Sense & TTA TCT TTC ATT GAT CAT ATT ATG AGG & $772-798$ & 525 & AJ243415 \\
\hline & Antisense & CTA GGT AAT CTA GAG AAC AAG ATA TCG & 1271-1297 & & \\
\hline
\end{tabular}



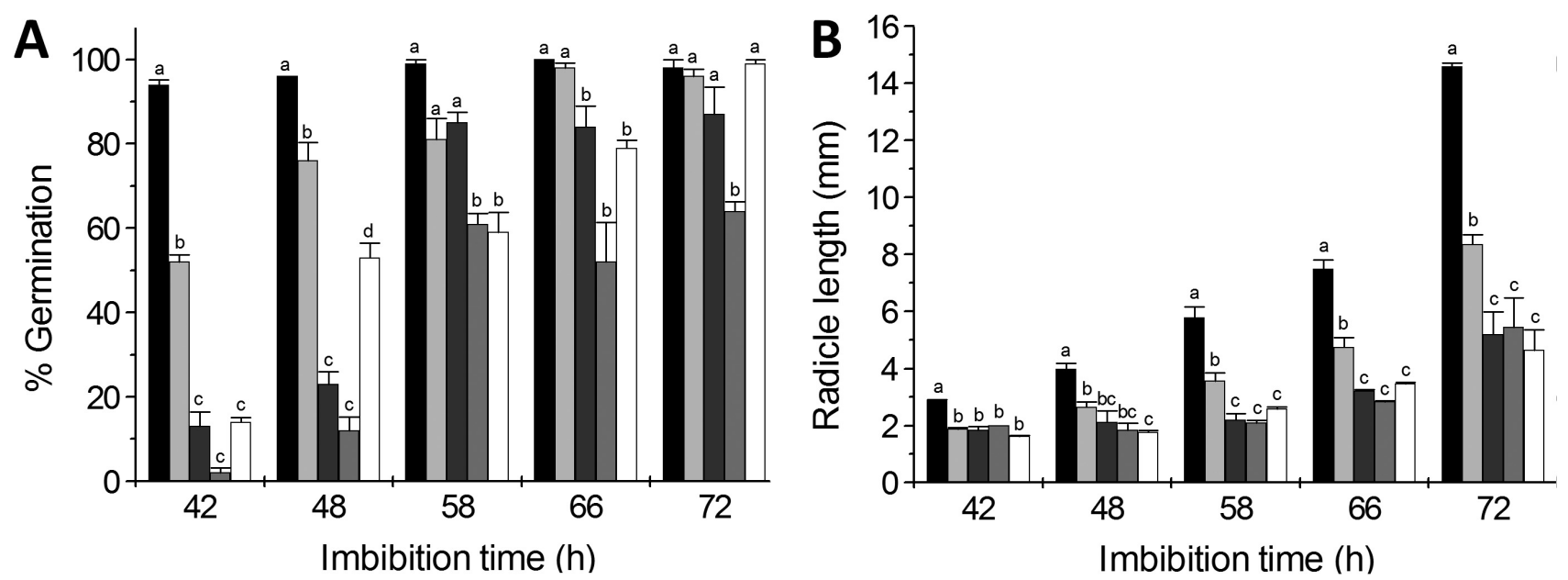

Figure 1. Effect on germination and radical growth in increasing concentrations of ABA and $0.5 \%$ Sicyos deppei aqueous leachate. (A) Effects of ABA at 0 (control, $\square$ ), $2(\square), 5(\square)$ and $10 \mu \mathrm{M} \mathrm{ABA}$ ( $\square$ ), and $0.5 \%$ S. deppei leachate ( $\square$ ) on tomato seed germination. (B) Radicle growth $(\mathrm{mm})$. Mean \pm s.d., $\mathrm{n}=3$. Different letters indicate significance at $P<0.05$ among treatments from each analyzed time.

acid (ABA) content was previously observed in tomato seeds incubated with the aqueous leachate of S. deppei $(0.5 \%)$ compared with that of control seeds during germination, resulting in decreased germination rate, delayed root protrusion and growth inhibition (Lara-Núñez et al., 2009). We compared the effect of $S$. deppei aqueous leachate with the effects of different exogenous concentrations of $\operatorname{ABA}(0,2,5$ and 10 $\mu \mathrm{M}$ ) on germination and radicle growth (Figure 1A, B). At 42 $\mathrm{h}$, increasing levels of exogenous ABA inhibited tomato seed germination, and 5 and $10 \mu \mathrm{M} \mathrm{ABA}$ caused effects similar to those obtained with $S$. deppei leachate (Figure 1A). However, $10 \mu \mathrm{M}$ of ABA caused the highest inhibition at all times. At 58 and $66 \mathrm{~h}$ there was no difference in the germination between $10 \mu \mathrm{M}$ ABA and S. deppei aqueous leachate; at $72 \mathrm{~h}$, the seeds exposed to $S$. deppei obtained the same germination as control, but not seeds treated with $10 \mu \mathrm{M} \mathrm{ABA}$.

Similar to germination, the radicle length was also inhibited after these treatments, and there was no significant difference between Sicyos deppei aqueous leachate and the ABA concentrations (Figure 1B). Longer incubation times resulted in a stronger inhibition of radicle growth, with 5 and $10 \mu \mathrm{M} \mathrm{ABA}$ and Sicyos (36\% at $72 \mathrm{~h}$ ) compared with control seeds.

To determine whether Sicyos deppei interferes with ABA catabolism, tomato seeds were incubated with $10 \mu \mathrm{M}$ diniconozole, $10 \mu \mathrm{M} \mathrm{ABA}$ and $0.5 \% \mathrm{~S}$. deppei aqueous leachate, and subsequently the internal ABA content was measured at 24, 36 and $48 \mathrm{~h}$. Diniconazole is a fungicide and a potent competitive inhibitor of the recombinant Arabidopsis ABA 8'-hydroxylase, CYP707A3. This fungicide has been used in studies to repress ABA catabolism (Kitahata et al., 2005; Zhu and Zhang, 2009; Zhua et al., 2011). We selected $10 \mu \mathrm{M}$ diniconazole because the inhibition of root elongation was affected similarly to $0.5 \% \mathrm{~S}$. deppei aqueous leachate at $72 \mathrm{~h}$ (data not shown).
Figure 2 shows that in control seeds, ABA is degraded as germination proceeds, reaching $87 \%$ ABA removal at $48 \mathrm{~h}$ compared with control seeds at $0 \mathrm{~h}$, while in seeds exposed to Sicyos deppei only $28 \%$ ABA removal was obtained within the same time. ABA degradation was also slower after diniconazole and $S$. deppei treatments, but not at the expected levels, as we anticipated less degradation if diniconazole acts as an ABA catabolism inhibitor. Notably at 48 $\mathrm{h}$, the seeds exposed to exogenous ABA had less ABA content than those treated with $S$. deppei aqueous leachate, and the ABA levels were similar to the level observed in seeds following diniconazole treatment.

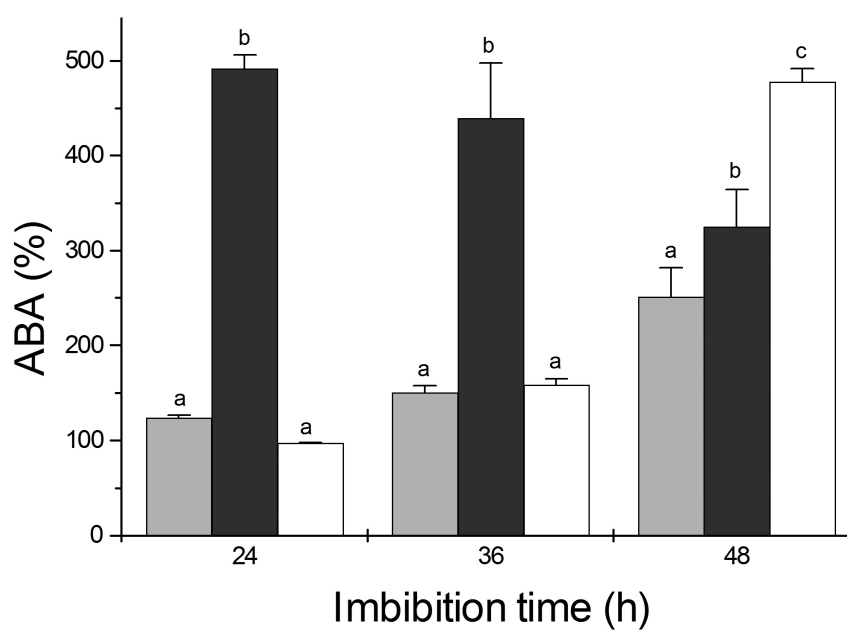

Figure 2. Effect of exogenous ABA, diniconazole and aqueous leachate of Sicyos deppei on the ABA content in germinating tomato seeds. Treatments: Diniconazole $(10 \mu \mathrm{M}, \square)$, exogenous ABA $(10 \mu \mathrm{M}, \square)$ and $S$. deppei leachate $(0.5 \%, \square)$. ABA content is expressed as a percentage of ABA on control seed at each analyzed time. Mean \pm s .d., $n=3$. Different letters indicate significance at $P<0.05$ among treatments from each analyzed time. 

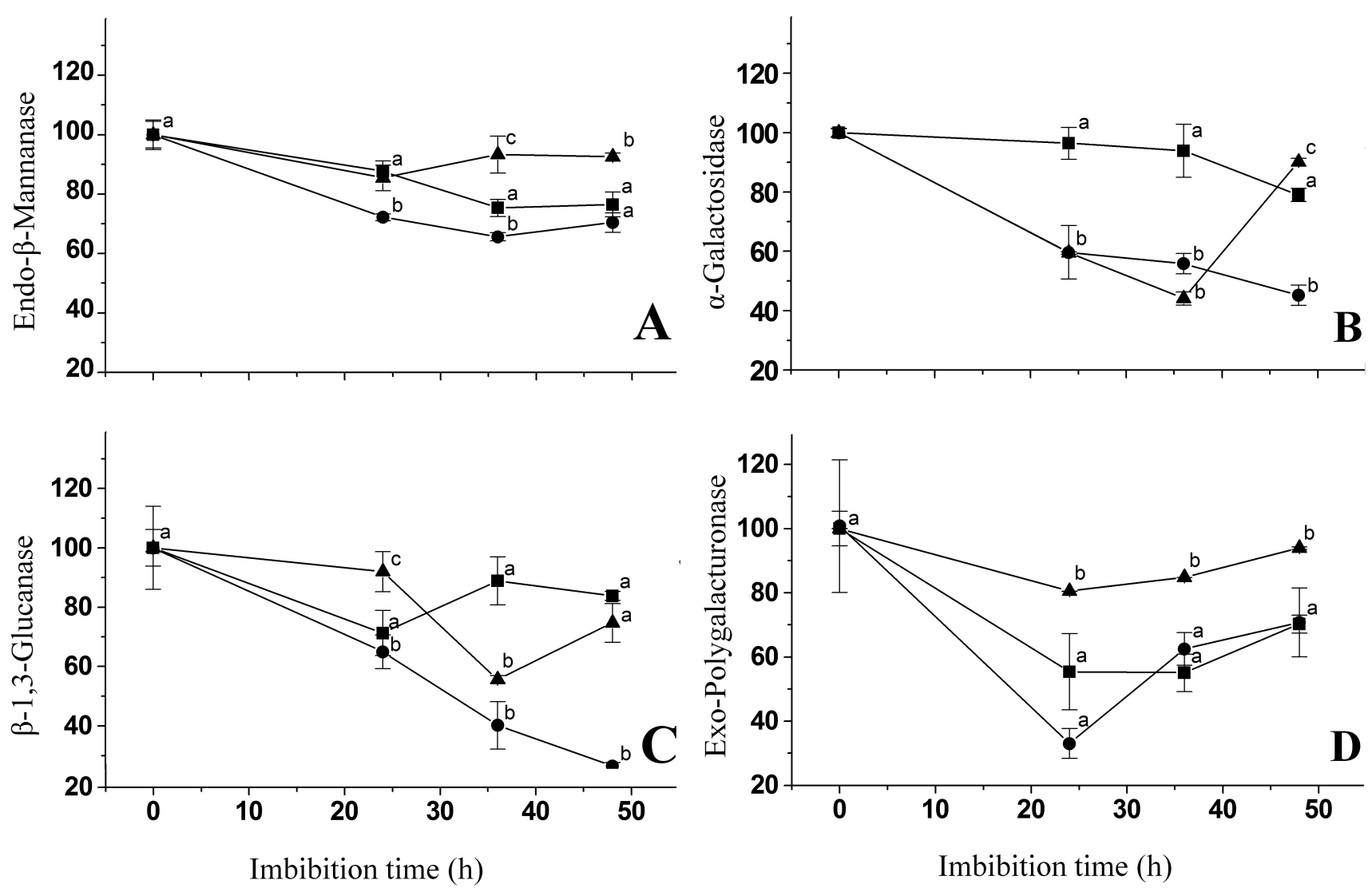

Figure 3. Effect of ABA, diniconazole and Sicyos deppei aqueous leachate on cell wall-degrading enzymes during tomato seed germination. (A) Endo- $\beta$-Mannanase, (B) $\alpha$-Galactosidase, (C) $\beta$-1,3-Glucosidase, (D)-Exo-Polygalacturonase. Enzymatic activities at 0, 24,36 and $48 \mathrm{~h}$ are expressed as a percentage of those in control seeds at the analyzed imbibition times. $10 \mu \mathrm{M}$ Diniconazole $(\boldsymbol{\square}), 10 \mu \mathrm{M}$ ABA (O) and $S$. deppei aqueous leachate $(0.5 \%)(\mathbf{\Delta})$. Mean \pm s.d., $\mathrm{n}=3$. Different letters indicate significance at $P<0.05$ among treatments at each analyzed time.

Effect of Diniconazole and ABA on the enzyme activity involved in cell wall degradation or endosperm weakening. In a previous work, we reported a low activity of the cell walldegrading enzymes, endo- $\beta$-D-mannanase, $\alpha$-galactosidase, $\beta$-1,3-glucanase, and exo-polygalacturonase, in seeds exposed to $S$. deppei leachate (Lara-Núnez et al., 2009). The activity of most of these enzymes was regulated through ABA during germination (Toorop et al., 2000; LeubnerMetzger et al., 1995). Here, we analyzed the activity of these enzymes in seeds exposed to exogenous $\mathrm{ABA}(10 \mu \mathrm{M})$ and diniconazole $(10 \mu \mathrm{M})$, to examine the hypothesis that $S$. deppei induces higher levels of ABA to regulate the activity of these enzymes in a similar manner.

Figure 3 shows the activity of these enzymes as percentage of the control to obtain a better comparison among the treatments. The activity of $\alpha$-Galactosidase was severely reduced in seeds treated with ABA and Sicyos deppei aqueous leachate; however in seedlings treated with $S$. deppei aqueous leachate an increase up to almost control levels of activity was observed at $48 \mathrm{~h}$ after treatment. Interestingly, a reduction in the activity of $\alpha$-Galactosidase was only observed at $48 \mathrm{~h}$ after diniconazole treatment (Figure 3B).
The $\beta-1,3-$ Glucanase activity was also severely decreased in seeds treated with ABA, and $S$. deppei treatment significantly reduced activity up to $36 \mathrm{~h}$, and subsequently this activity was recovered at $48 \mathrm{~h}$, but remained lowered than the control. The activity in seeds treated with diniconazole was reduced at $24 \mathrm{~h}$ and subsequently recovered to levels similar to the activity with $S$. deppei at $48 \mathrm{~h}$ (Figure 3C). Exo-polygalacturonase activity decreased severely in seeds treated with ABA and diniconazole. Sicyos deppei treatment also reduced it, but to a lesser extent; subsequently, enzymatic activity was recovered at 36 and 48 h (Figure 3D).

Interference of Sicyos deppei aqueous phytotoxic leachate on tomato cell cycle. We have shown that $S$. deppei aqueous leachate causes a delay in the germination rate and inhibits radicle elongation in tomato seeds. To explain root growth inhibition, we proposed that phytotoxic compounds present in the aqueous leachate of $S$. deppei could negatively affect cell division at proliferating roots tips. We analyzed the expression of three key cell cycle proteins, which play an important role in cell cycle regulation and progression. We chose two mitosis-specific genes $C Y C B 2 ; 1$ and $C D K B 2 ; 1$, 
A
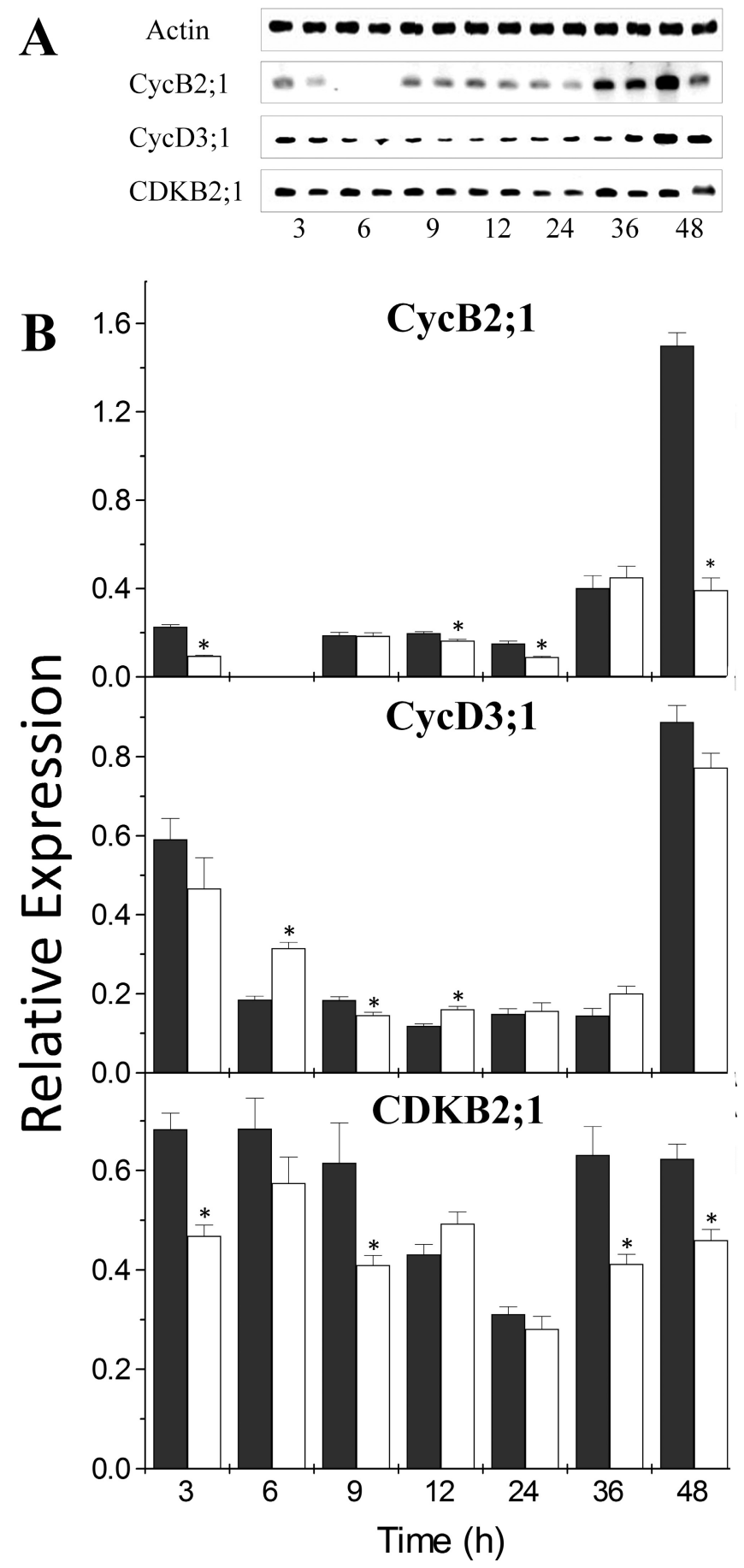

Figure 4. Effect of Sicyos deppei aqueous leachate on the mRNA expression of cell cycle markers in germinating tomato seeds. (A) mRNA expression of Actin (as control), $C y c B 2 ; 1, C y c D 3 ; 1$ and $C D K B 2 ; 1$ in control tomato seeds ( $\mathbf{\square})$ or $S$. deppei aqueous leachate $(\square)$ on germination at 3, 6, 9, 12, 24, 36 and 48 h after imbibition. (B) The relative expression was calculated as the density of each band divided by the density of the actin control at each time. Mean \pm s.d., $\mathrm{n}=3$. * indicates significance at $P<0.05$ among treatments at each analyzed time. and $C Y C D 3 ; 1$, a D-type cyclin that is potentially involved in cell cycle regulation in response to mitogenic signals at the G1-S interphase (Baldet et al., 2006).

Figure 4 shows the mRNA expression profile of the three cell cycle proteins during the first hours of germination and post-germination. The expression of $C Y C B 2 ; 1$ showed a significant decrease at 3,12 , and $24 \mathrm{~h}$ in treated seeds compared with the control. Notably, at $48 \mathrm{~h}$, the expression of CYCB2;1 exhibited a 4-fold down regulation compared with control seedlings. In Arabidopsis, CycB type proteins promote root growth and induce mitotic division (Van Leene et al., 2011).

The expression of $C Y C D 3 ; 1$ was high at $3 \mathrm{~h}$, and subsequently down regulated after both control and Sicyos deppei treatment, with lower mRNA levels observed in the control and significantly higher levels observed in Sicyos-treated seeds at 6 and $12 \mathrm{~h}$; even lower levels were observed after 9 h. In Arabidopsis, CycD3;1 is hormone responsive, particularly to cytokinins, promoting the transition from the $\mathrm{G}_{1}$ to $\mathrm{S}$ phase (Nieuwland et al., 2007). The expression of $C D K B 2 ; 1$ in the treated seeds was lower at most of the times analyzed.

In a second approach to analyze if there was a perturbation in the cell cycle and to confirm the previous result, the progression of cell cycle was analyzed through DNA replication (Figure 5A-D). The general consensus is that prior to radicle protrusion, radicle cells might contain only $2 \mathrm{C}$ DNA, or only a portion of the cells might contain 4C DNA (Bewley and Black, 1994). Furthermore, mitosis only occurs after radicle protrusion, i.e., at the onset of seedling growth (Coolbear and Grierson, 1979; Haigh, 1988). Cell progression was analyzed using flow cytometry at root tips because mitosis takes place in this tissue at $48 \mathrm{~h}$, as radicle protrusion is typically initiated at this time (Figure 1B). In control seeds at 48 and $72 \mathrm{~h}$, a predominance of $2 \mathrm{C}$ DNA content, i.e., nuclei at the G1 phase, was observed. However, treated seeds at 48 and $72 \mathrm{~h}$ showed minor $2 \mathrm{C}$ DNA and higher 4C DNA content.

\section{Discussion}

Sicyos deppei aqueous leachate and exogenous ABA were able to delay tomato germination radicle length in a similar proportion. When the internal ABA level on seeds was analyzed the results suggested that $S$. deppei aqueous leachate might maintain higher levels of ABA, acting as ABA catabolism inhibitor, which yields stronger effects than observed using the concentration of diniconazole used here $(10 \mu \mathrm{M})$. There is also the possibility that the aqueous leachate of $S$. deppei might enhance ABA biosynthesis.

In a previous work we reported a low cell wall-degrading activities of some enzymes and that most of them could be regulated by $\mathrm{ABA}$ we analyzed in the present work the activity of four cell wall degrading enzymes under Sicyos 

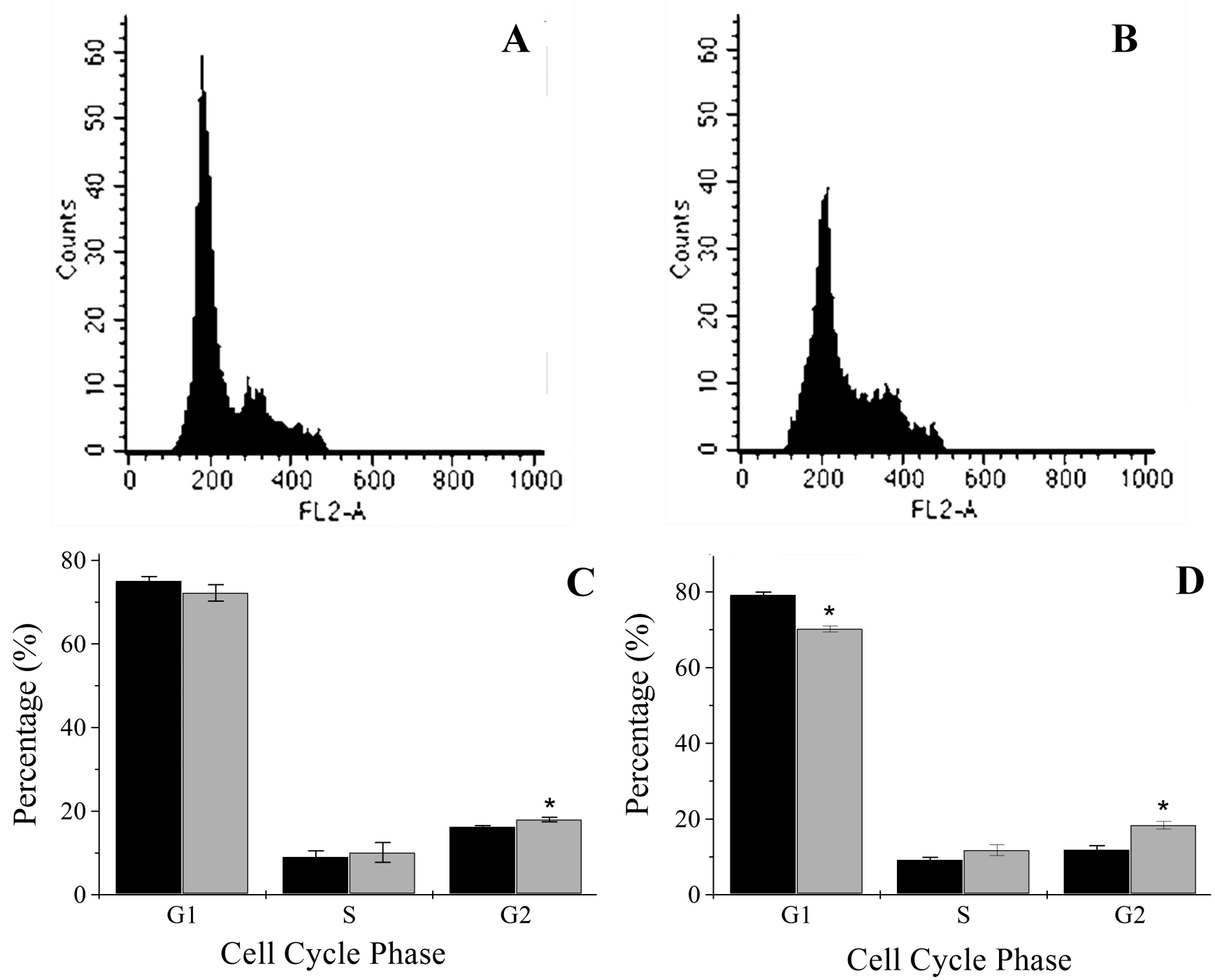

Figure 5. DNA content through Flow cytometry: (A) A flow cytometry histogram of control seeds and (B) seeds treated with Sicyos deppei aqueous leachate at $72 \mathrm{~h}$. The percentage of nuclei in G1, S or G2 phase in control ( $\boldsymbol{\square})$ or treated tomato seeds ( $\square$ ) at (C) 48 and (D) $72 \mathrm{~h}$. Each experiment was performed with independent triplicates. Mean \pm s.d., $\mathrm{n}=3$. * Indicates significance at $P<0.05$ among each analyzed phase.

deppei, $\mathrm{ABA}$ and diniconazle treatment: endo- $\beta$-D-mannanase, $\alpha$-galactosidase, $\beta$-1,3-glucanase, and exo-polygalacturonase. Results showed that $S$. deppei, exogenous ABA, and diniconazole exert an inhibitory effect on the activity of the enzymes involved in cell wall degradation or endosperm weakening, although at different response levels. Although all of these treatments caused inhibition, the effect of the aqueous leachate of $S$. deppei $i$ was less than that obtained with the other treatments, and with time, the activity of these enzymes increased. Under all treatments higher ABA levels at $48 \mathrm{~h}$ were observed compared with control seeds, thus indicating that ABA interferes with the activity of these enzymes. High levels of ABA and the decrease in activity of $\beta-1,3$-Glucanase and $\alpha$-Galactosidase at early germination stages, as observed in this study and reported previously (Leubner-Metzger et al., 1995; Toorop et al., 2000), resulted in the suppression of endosperm rupture, thus delaying radicle protrusion. This reduction in cell wall enzymatic activity, primarily during early germination times, could be responsible for the delay in the radicle protrusion during germination. Thus, these results show that $S$. deppei might interfere with ABA catabolism, as enzyme levels are still high at this time ( $48 \mathrm{~h}$ ), however enzyme activity could also be regulated through other factors in addition to ABA, explaining the recovery of activity of $\beta$ 1,3 -glucanase, $\alpha$-galactosidase and exo-polygalacturonase at longer times of treatment.

Since Sicyos deppei aqueous leachate delayed germination rate and inhibited radicle elongation in tomato seeds we explored the possibility that the cell cycle might be affected. Thus, the expression of three genes related to cell cycle (CYCB2;1 and CDKB2;1, and CYCD3;1) was analyzed in seeds under $S$. deppei treatment throughout germination. 
It was found a down regulation of CYCB2;1 expression, which is essential for mitosis (Van Leene et al., 2011). A decrease in its expression might indicate that fewer cells complete the first round of cell division. Particularly, the events occurring at $48 \mathrm{~h}$ are of great interest because in tomato seeds, the G2-M transition occurs more often (de Castro et $a l ., 2000)$ and the radicle emerges. In Arabidopsis an ana$\log$ of CDKB2;1, CDKB 1;1 shows an outbreak expression coincident with radicle protrusion (Barrôco et al., 2005). At this time, there was a reduction in gene expression of both mitotic markers CYCB2;1 and CDKB2;1. These two genes have been identified only in proliferating tissues and are involved in the G2-M transition; in this context, their expression is strongly regulated during cell cycle progression (Dudits et al., 2007; Nieuwland et al, 2007).

Cell proliferation is controlled through signals, such as sugar and plant regulators. For instance $A t C y c D 3$ genes are induced by cytokinin (Riou-Khamlichi et al., 1999). AtCycD3;1 is also induced by auxins (del Pozo et al, 2004) and sucrose (Riou-Khamlichi et al., 2000), while two CycD3 from Snapdragon are down-regulated by ABA (Gaudin et $a l ., 2000)$. In this study, the down-regulated expression of genes involved in cell cycle was observed at $48 \mathrm{~h}$ in tomato seeds under Sicyos deppei aqueous leachate treatment and might be associated with an imbalance in ABA catabolism, as higher amounts of this hormone were observed at $48 \mathrm{~h}$. Other plant regulators could also be impaired in treated seeds, which could also exert an effect on cell cycle proteins and mRNA expression. Our results are consistent with those of Zhang et al. (2010) showing that an aqueous extract in the roots and a hydrophobic root exudate of cucumber down-regulated the expression of cell cycle-related genes, such as $C y c D 3 ; 1$ and $C D K A$ from cucumber radicles exposed to these two phytotoxic extracts.

The DNA replication analysis trough flow cytometry indicated that seeds under treatment had a higher number of cells with 4C DNA content than control, implying that more cells were delayed thus remaining more time at the G2 phase, and therefore exhibited a lower mitosis rate. Zhang et al. (2010) showed that the aqueous root extract and the hydrophobic root exudate of cucumber affected the nuclei DNA content of treated cucumber roots. The results on DNA content, together with the reduction observed in the expression of cell cycle markers (Figure 4), suggests that Sicyos deppei aqueous leachate affects cell cycle progression, and causes radicle growth inhibition. Previously, we reported that seeds exposed to $S$. deppei leachate experienced increased levels of oxidative stress (Lara-Núñez et al., 2009), which could be related to cell cycle inhibition. Reichheld $e t$ al. (1999) showed that tobacco cells, under mild oxidative stress, experience the inhibition of cell division in both cell suspensions and plants. A delay in ABA catabolism could also contribute to the global effect of cell delay at the G2-M transition.
Overall, the results obtained in this study suggest that the mixture of aqueous compounds in Sicyos deppei leachate could interfere with ABA catabolism, as cell wall-degrading enzyme activities are affected in a similar manner under allelochemical stress and diniconazole (an ABA catabolism inhibitor) treatment at $48 \mathrm{~h}$. The observed delay in germination could reflect the increased amount of $\mathrm{ABA}$, and the inhibition of the activity of these cell wall enzymes. Notably, although absolute concentrations of ABA are indicative of the processes occurring in a tissue, potential changes in the sensitivity to ABA over time should also be considered. Other plant regulators, such as auxins and cytokinins, might also be imbalanced in treated seed and partial effects could contribute to the global delay in germination and radicle growth imparity. On the other hand, the inhibition of radicle growth can be associated with the down-regulation of the expression of key proteins that regulate the cell cycle, such as cyclin $\mathrm{B}$ and CDKs, and thereby reducing its rate. This evidence was confirmed using flow cytometry, which led us to conclude that the nuclei in treated seeds had greater $4 \mathrm{C}$ DNA content and therefore more cells were at the G2-M transition, implying an evident delay in the cell cycle.

According to the results reached in this work and to those obtained from other studies about the aqueous leachate of Sicyos deppei (Romero-Romero et al., 2005; Lara-Núñez et al., 2006, 2009), we provide a more complete understanding of how the compounds present in this extract cause phytotoxicity in tomato germinating seeds, as evidenced through a delay in germination process and radicle growth inhibition.

\section{Acknowledgments}

This work was supported by grants from the Dirección General de Asuntos del Personal Académico (PAPIIT IN205705 and IN226607) from the Universidad Nacional Autónoma de México, UNAM. We also would like to thank to Química Agrónoma, Blanca Estela Hernández Bautista her valuable technical help. We also acknowledge the anonymous reviewers for their valuable reviews.

\section{Literature cited}

Baldet P., Hernould M., Laporte F., Mounet F., Just D., Mouras A., Chevalier C. and Rothan C. 2006. The expression of cell proliferation-related genes in early developing flowers is affected by a fruit load reduction in tomato plants. Journal of Experimental Botany 57:961-970.

Barrôco R.M., Van Poucke K., Bergervoet J.H.W., De Vaylder L., Groot S.P.C., Inzé D. and Engler G. 2005. The role of the cell cycle machinery in resumption of postembryonic development. Plant Physiology 137:127-140.

Bewley J.D. and Black M. 1994. Seeds: Physiology of Development and Germination. Springer Science+Business Media, New York.

Bradford M.R. 1976. A rapid and sensitive method for the quanti- 
tation of microgram quantities of protein utilizing the principle of protein-dye binding. Annals of Biochemistry 72:248-254.

Coolbear P. and Grierson D. 1979. Studies on the changes in the major nucleic acid components of tomato seeds (Lycopersicon esculentum Mill) resulting from osmotic presowing treatments. Journal of Experimental Botany 30:1153-1162.

Crosgrove D.J. 1996. Plant enlargement and the action of expansins. BioEssays 18:533-540.

Cruz-Ortega R., Anaya A.L., Hernández B.E. and Laguna-Hernández G. 1998. Effects of allelochemical stress produced by Sicyos deppei on seedling root ultrastructure of Phaseolus vulgaris and Cucurbita ficifolia. Journal of Chemical Ecology 24:2039-2057.

de Castro R.D., van Lammeren A.A., Groot S.P., Bino R.J.and Hilhorst H.W. 2000. Cell Division and subsequent radicle protrusion in tomato seeds are inhibited by osmotic stress but DNA synthesis and formation of microtubular cytoskeleton are not. Plant Physiology 122:327-336.

del Pozo J.C., Lopez-Matas M.A., Ramirez-Parra E. and Gutierrez C. 2004. Hormonal control of the plant cell cycle. Physiologia Plantarum 123:173-183.

Dudits D., Cserháti M., Miskolczi P. and Horváth G.V. 2007. The growing family of plant cyclin-dependent kinases with multiple functions in cellular and developmental regulation In: Inzé D. Ed. Cell Cycle Control and Plant Development, pp. 1-30, Blackwell Publishing, Oxford.

Feurtado J.A., Banik M. and Bewley J.D. 2001. The cloning and characterization of $\alpha$-galactosidase present during and following germination of tomato (Lycopersicon esculentum Mill.) seed. Journal of Experimental Botany 52:1239-1249.

Finch-Savage W.E. and Leubner-Metgzer G. 2006. Seed dormancy and the control of germination. New Phytologist 171:501-523.

Gaudin V., Lunness P.A., Fobert P.R., Towers M., Riou-Khamlichi C., Murray J.A., Coen E. and Doonan J.H. 2000. The expression of D-cyclin genes defines distinct developmental zones in snapdragon apical meristems and is locally regulated by the $C y$ cloidea gene. Plant Physiology 122:1137-1148.

Haigh A.M. 1988. Why do tomato seed prime?: physiological investigations into the control of tomato seed germination and priming. Ph.D. Dissertation, Macquarie University, Sydney $121 \mathrm{pp}$.

Inzé D. and De Veylder L. 2006. Cell cycle regulation in plant development. Annual Review of Genetics 40:77-105.

Kitahata N., Saito S., Miyazawa Y., Umezawa T., Shimada Y., Min Y.K., Mizutani M., Hirai N., Shinozaki K., Yoshida S. and Asami T. 2005. Chemical regulation of abscisic acid catabolism in plants by cytochrome $\mathrm{P} 450$ inhibitors. Bioorganic and Medicinal Chemistry 13:4491-4498.

Lara-Núñez A., Romero-Romero T., Ventura J.L., Blancas V., Anaya A.L. and Cruz-Ortega. R 2006. Allelochemical stress causes inhibition of growth and oxidative damage in Lycopersicon esculentum Mill. Plant Cell and Environment 29:2009-2016.

Lara-Núñez A., Sanchez-Nieto S., Anaya A.L. and Cruz-Ortega R. 2009. Phytotoxic effects of Sicyos deppei (Cucurbitaceae) in germinating tomato seeds. Physiologia Plantarum 136:180-92.

Leubner-Metzger G. 2003. Functions and regulation of $\beta$-1,3-glucanases during seed germination, dormancy release and afterripening. Seed Science Research 13:17-34.

Leubner-Metzger G., Fründt C., Vögeli-Lange R. and Meins F Jr. 1995. Class I $\beta$-1,3-glucanases in the endosperm of tobacco during germination. Plant Physiology 109:751-759.
Leung D.W.N. and Bewley J.D. 1981. Red-light- and gibberellicacid-enhanced $\alpha$-galactosidase activity in germinating lettuce seeds, cv. Grand Rapids: Control by the axis. Planta 152:436441.

Morohashi Y. and Matsushima H. 2000. Development of $\beta-1,3-$ glucanase activity in germinated tomato seeds. Journal of Experimental Botany 349:1381-1387.

Nieuwland J., Menges M. and Murray J.A.H. 2007. The plant cyclins. In: Inzé D. Ed. Cell Cycle Control and Plant Development, pp. 31-61, Blackwell Publishing, Oxford.

Nonogaki H., Gee O.H. and Bradford K.J. 2000. A germinationspecific endo- $\beta$-mannanase gene is expressed in the micropylar endosperm cap of tomato seeds. Plant Physiology 123:12351245.

Özbingöl N., Corbineau F., Groot S.P.C., Bino R.J. and Côme D. 1999. Activation of the cell cycle in tomato (Lycopersicon esculentum Mill.) seeds during osmoconditioning as related to temperature and oxygen. Annals of Botany 84:245-251.

Reichheld J.P., Vernoux T., Lardon F., Van Montagu M. and Inzé D. 1999. Specific checkpoints regulate plant cell cycle progression in response to oxidative stress. Plant Journal 17:647-656.

Reid J.S.G. and Meier H. 1973. Enzymatic activities and galactomannan movilisation in germinating seeds of fenugreek (Trigonella foenum-graecum L. Leguminosae). Secretion of $\alpha$ galactosidase and $\beta$-mannosidase by the aleurone layer. Planta 112:301-308.

Riou-Khamlichi C., Huntley R., Jacqmard A. and Murray J.A.H. 1999. Cytokinin activation of Arabidopsis cell division through a D-type cyckin. Science 283:1541-1544.

Riou-Khamlichi C., Menges M., Healy J.M. and Murray J.A. 2000. Sugar control of the plant cell cycle: differential regulation of Arabidopsis D-type cyclin gene expression. Molecular Cell Biology 20:4513-4521.

Romero-Romero T., Anaya A.L. and Cruz-Ortega R. 2002. Screening for effects of phytochemical variability on cytoplasmic protein synthesis pattern of crop plants. Journal of Chemical Ecology 28:617-629.

Romero-Romero T., Sánchez-Nieto S., SanJuan-Badillo A., Anaya A.L. and Cruz-Ortega R. 2005. Comparative effects of allelochemical and water stress in roots of Lycopersicon esculentum Mill. (Solanaceae). Plant Science 168: 1059-1066.

Sacandé M., Groot S.P.C., Hoekstra F.A., De Castro R.D. and Bino R.J. 1997. Cell cycle events in developing neem (Azadirachta indica) seeds: are they related to intermediate storage behaviour? Seed Science Research 7:161-168.

Salyers J.K., Palmer J.K. and Wilkins T.D. 1977. Laminarinase ( $\beta$-glucanase) activity in Bacteroids from the human colon. Applied and Environmental Microbiology 33:1118-1124.

Sitrit Y., Hadfield K.A., Bennett A.B., Bradford K.J. and Downie A.B. 1999. Expression of a polygalacturonase associated with tomato seed germination. Plant Physiology 121:419-428.

Still D.W., Dahal P. and Bradford K.J. 1997. A single-seed assay for endo- $\beta$-mannanase activity from tomato endosperm and radicle tissues. Plant Physiology 113:13-20.

Tagawa K. and Kaji A. 1988. Polygalacturonase from Corticium rolfsii. Methods in Enzymology 161:361-365.

Tahara M., Guenzi A.C., Read J.J., Carver B.F. and Johnson R.C. 1991. Quantification of Abscisic acid in wheat leaf tissue by direct enzyme immunoassay. Crop Science 31:1185-1189. 
Tank J.G. and Thaker V.S. 2011. Cyclin dependent kinases and their role in regulation of plant cell cycle. Biologia Plantarum 55:201-212.

Toorop P.E., van Aelst A.C. and Hilhorst H.W.M. 2000. The second step of the biphasic endosperm cap weakening that mediates tomato (Lycopersicon esculentum) seed germination is under control of ABA. Journal of Experimental Botany 51:1371-1379.

Van Leene J., Boruc J., De Jaeger G., Russinova E. and De Veylder L. 2011. A kaleidoscopic view of the core cell cycle interactome. Trends in Plant Science 16:141-150.

Vázquez-Ramos J.M. and Lara-Nuñez A. 2008. Cyclins D, phytoregulators and cell cycle onset in germinating maize. Plant Signaling and Behavior 3:578-579.

Villaseñor-Ríos J.L. and Espinosa-García F.J. 1988. Catálogo de Malezas de México. Universidad Nacional Autónoma de Méxi- co, Consejo Nacional Consultivo Fitosanitario. Fondo de Cultura Económica, México, D.F.

Zhang Y., Gu M., Shi K., Zhou Y.H. and Yu J.Q. 2010. Effects of aqueous root extracts and hydrophobic root exudates of cucumber (Cucumis sativus L.) on nuclei DNA content and expresión of cell cycle-related genes in cucumber radicles. Plant and Soil 327:455-463.

Zhu G., Ye N. and Zhang J. 2009. Glucose-induced delay of seed germination in rice is mediated by the suppression of ABA catabolism rather than an enhancement of ABA biosynthesis. Plant Cell and Physiology 50:644-651.

Zhua G., Liu Y., Ye N., Liu R. and Zhang J. 2011. Involvement of the abscisic acid catabolic gene CYP707A2 in the glucose-induced delay in seed germination and post-germination growth of Arabidopsis. Physiologia Plantarum 143:375-384.

Received: July 1st, 2014

Accepted : September 2nd, 2014 